Article

\title{
Green and Blue Infrastructure in Darwin; Carbon Economies and the Social and Cultural Dimensions of Valuing Urban Mangroves in Australia
}

\author{
Jennifer Atchison
}

Australian Centre for Culture, Environment, Society and Space (ACCESS), University of Wollongong, Northfields Avenue, Wollongong, NSW 2522, Australia; jennya@uow.edu.au

Received: 26 June 2019; Accepted: 29 July 2019; Published: 31 July 2019

\begin{abstract}
Darwin's mangrove ecosystems, some of the most extensive and biodiverse in the world, are part of the urban fabric in the tropical north of Australia but they are also clearly at risk from the current scale and pace of development. Climate motivated market-based responses, the so-called 'new-carbon economies', are one prominent approach to thinking differently about the value of living infrastructure and how it might provide for and improve liveability. In the Australian context, there are recent efforts to promote mangrove ecosystems as blue infrastructure, specifically as blue carbon, but also little recognition or valuation of them as green or urban infrastructure. Drawing on observational and qualitative analysis of semi-structured interviews, this study examines how key stakeholders in Darwin frame and understand mangroves in relation to the urban, and how they are anticipating and responding to governance efforts to frame mangroves and pay for their carbon sequestration and storage services as blue carbon. The push for large infrastructure development and an expanding urban footprint, present serious challenges for mangrove protection, and the study evidences both denial and complacency in this regard. However, although the concept of blue carbon is already taking effect in some circles, it was not viewed as straightforward or as appropriate by all study participants and may very well work in practice to exclude groups within the community. Both clear governance problems, as well as unrecognized and vernacular community connections to mangroves in Darwin, indicate that there are ongoing conceptual and empirical challenges to be considered in recognizing and valuing mangroves as part of urban life.
\end{abstract}

Keywords: green infrastructure; blue infrastructure; mangroves; Darwin; Australia; social and cultural values; carbon economies; urban forest

\section{Introduction}

Vegetation framed as 'green infrastructure' is increasingly posited as a key solution to many of the escalating climate, environmental and human health threats faced in the world's cities [1-6]. Plants are already understood to provide multiple services and/or benefits to humans in urban areas, for example in the form of mitigated urban heat effects or green spaces for pollution mitigation and opportunities for recreation [4-6]. Additionally, as urban vegetation is recognised as heterogeneous [7], urban plants are also understood to provide multiple services and benefits to wider communities as they improve connectivity within urban spaces and surrounding ecological systems, supporting the biodiversity and ecological function of the systems in which cities are embedded [8]. These combined services and multiple or co-benefits of urban vegetation mean that increasing vegetation cover is a key issue for urban municipalities and planners seeking to improve liveability, resilience, and social and ecological connectedness [9]. How to get more plants in, and where they will fit, are focus questions for contemporary urban research policy and practice [10]. However, often overlooked is the 
protection and management of existing vegetation in cities or acknowledgement and prioritisation of the services plants are already known to provide [11-13]. There are inherent and ongoing tensions in focusing on planting new trees for example, while existing trees continue to be cleared for other urban infrastructure, for urban expansion, renewal and/or densification [14-16]. Understanding how existing vegetation is understood, valued and protected in urban areas is therefore, a key question for green infrastructure research.

Mangroves and the assemblage of plants that live in the intertidal zone, sit at this tense and rapidly changing interface between growing recognition of the need for more vegetation in cities and the impacts to existing vegetation from expanding and intensifying urban development. This is especially the case in the world's tropical cities, which are a focus of scientific concern related to the numerous and rising severity of threats to urban liveability from climate change, including from coastal inundation, cyclone activity and heat events [17-19], and which are also undergoing rapid population growth [20]. In order to advance knowledge about existing mangroves in urban areas, this paper argues that mangroves and associated ecosystems also sit at the intersection between important and emergent debates on both green and blue infrastructure and that there are key reasons to consider how mangroves are currently defined, understood and managed. In part, the paper is prompted by the difficulty of locating mangroves and associated ecosystems within existing living infrastructure definitions, conceptual frameworks and typologies. Geographic biases against tropical cities in existing data sets [21], and the use of catch-all terms such as 'blue-green' that are not defined, or do not refer to or capture marine ecosystems [22,23] for example, are both at play. Referring to vegetation as infrastructure might appear, in a practical sense at least, to provide a connective means for people and communities to acknowledge and value mangroves. However, research [24] illustrates that such terms not only serve as 'boundary objects' - linking groups of ideas and people, they also carry inherent risks, including diluting aligned, but very different interests, or becoming obsolete as concepts and agendas alike change [25]. Additionally, scholars from the social sciences and humanities have drawn attention to the specific cultural frames in which such concepts are themselves embedded and the complex and not necessarily neutral agendas they might serve [26,27]. Critically, green infrastructure is argued to be a contested concept and some have pointed out that resistance to its ambiguity is counterproductive [25]. Blue infrastructure has a more recent history, but is also argued to be less useful [28]. For these reasons, this study does not seek to predetermine, reify or classify any particular definition of green or blue infrastructure, but rather seeks to understand how communities understand mangroves in context, as well as how they respond to attempts to frame them as infrastructure in order to value them.

The critical services and benefits that mangroves provide are broadly recognized [29,30] however, mangroves are also under threat globally [31], and especially so in coastal urban areas where they continue to be cleared for both urban expansion, and infrastructure development, principally port and shipping facilities. In coastal urban areas, maintaining and increasing mangrove cover is understood to be an important component of combating the adverse impacts of climate change for urban populations (see for example [32]), but with the notable exception of recent efforts to steer away from so called grey infrastructure (encompassing engineered structures) and toward green infrastructure for coastal defence [33,34], mangroves are not often identified explicitly as green infrastructure [35].

Mangroves have featured prominently in ecosystem service based research examining marine infrastructure [36,37], especially as shore-line protection, as nurseries or critical habitat for coastal fisheries, and for their land-building capacity [38]. Significantly, increasing efforts to understand the role of mangroves in the global carbon cycle, indicates that mangroves represent a substantial above ground biomass on tropical shorelines, but also contribute considerably larger below ground carbon storage, a function or infrastructure service referred to as 'blue carbon' [39]. Recent research indicates this includes a capacity for significant carbon storage in urban contexts [40]. Additionally, as potential carbon sink, mangrove ecosystems are now also being linked to the 'blue economy' [41] 
as environmental economists and others consider the actions or works that might be put in place to protect and expand mangrove systems, paid for through payments for ecosystem services [42,43].

Focusing on tropical mangrove management in the Australian city of Darwin, this study presents empirical research using a qualitative social science approach to examine how key individuals in Darwin perceive the value of mangroves. This includes how they understand mangroves in relation to increasing development pressures, and how community groups are responding to governance interventions that are attempting to reframe mangroves, specifically as blue carbon, in order to protect them. Presenting original analysis of observations and semi-structured interviews with environmental mangers, government and non-government stakeholders and others, this research contributes to an understanding of the future of mangroves and their protection in urban tropical cities, highlighting how broader valuations of mangroves intersect with social and cultural values at a local level. It also contributes to discussions about the conceptual frameworks in place around mangroves and how these frameworks are themselves highly specific and potentially exclusionary forms of cultural valuation.

\section{Mangroves as Blue Carbon}

In an environmental management context, the instruments and logics of carbon are now being discussed, or are already operating to influence landscapes, environments and biodiversity and the way these are thought about and managed; savanna burning or carbon farming is a stand out example in the Australian context [44,45]. In these so-called 'new-carbon economies' [46], which have been described as an attempt to restructure how carbon is currently located in wider systems of value [47], carbon and its' credit may pay for conservation, control invasive species, provide alternative incomes or diversify land-use [48]. Broadly, but also diversely understood as market-based solutions to climate change, some [49] have argued these new ways of valuing carbon offer a potentially more enduring and productive process of exchange and trade which embed peoples' relations with carbon and with each other. Such attempts at valuing carbon differently hold the promise of re-organising and restructuring how the environment and ecosystems are valued and stewarded into the future however, the rush to operationalise presents spatial, political and social challenges. These challenges are known or starting to emerge in terrestrial carbon markets and they require ongoing research attention. For example, while some [50] have noted these schemes need to be designed with multiple or co-benefits in mind, and that design and co-benefits are the keys to success in terms of participation [51], others caution against over reliance on payments for ecosystem services to deliver win-win solutions [52]. Given the inconsistent success of ecosystem service payments in terrestrial contexts, scholars [53] are asking for renewed attention to carbon markets and payments in the emerging or new-carbon economies, both with regard to the social dimensions of schemes, but also to their promised environmental benefits.

'Blue carbon' represents something of a frontier within these new-carbon economies. Internationally, key projects are underway in diverse tropical settings [54] although there is still significant research focus on quantifying carbon stores in different settings and calculating service value [55,56]. Mangroves are a key ecosystem complex in the context of blue carbon due to their significant capacity for carbon sequestration and storage, however, calls for more attention and focus on the functionality, values and payments for the services of ecosystems often miss the mark in relation to mangrove systems based on social and cultural factors. For example, in different geographical contexts a history of seeing mangroves as wastelands, or sources of disease, suggests that economic evaluation alone may not be enough to reframe them positively or even to protect them [57]. Likewise, mangroves as ecosystems of embayments, are likely to remain under intense development pressure in terms of coastal port infrastructure [58].

Within Australia, the federal government is currently focused on reviewing the science and developing a new methodology that would see blue carbon, including from mangrove ecosystems, included in the national emissions reduction fund [59] and the extensive and relatively intact mangrove systems of the north are under scrutiny for their blue carbon potential. The landscapes of northern Australia are changing rapidly, with large infrastructure developments, a growing urban population and 
growing tourism and recreational industries presenting complex ecological governance challenges [60]. Climate change presents additional challenges as ecosystem boundaries, function and composition all change [61]. In this context, this study sought to examine how blue carbon and payments for the carbon storage services of mangroves were being anticipated, or not, in the urban coastal setting of Darwin. Darwin's mangroves are characterized as highly biodiverse and near pristine but are undergoing rapid change [62,63] as they face numerous impacts including legalised clearing for heavy industry and residential housing development, illegal clearing, alteration to hydrological function, pollution, and dredging [64]. These impacts are categorized in a national context as major despite the residential population being relatively small [65]. Although the social and cultural context for mangrove management and protection are understood to be underdeveloped areas of research, they are more commonly a focus in developing contexts where resource depletion and poor governance are often at issue [66]. One common assumption for example, is that the governance and management frameworks in place in Australia are relatively well developed, or offer sufficient protection [61].

\section{Materials and Methods}

The research reported here is part of a larger interdisciplinary project on the future of blue carbon as a mechanism for improving environmental management and carbon sequestration in northern Australia and comparative international case sites, including the Mekong Delta in Vietnam [67]. The social and cultural dimensions of blue carbon and mangroves are a key aspect of the research since systems of valuation, including ecosystem service valuations, are increasingly understood to be inherently cultural processes [68], but also because the individuals and people who are part of different stakeholder groups engage with and make value decisions informed by their social and cultural context including ethnicity, age, gender, education, economic situation and so on.

This paper draws on multi-sited ethnography [69], including semi-structured interviews with people and observation of their actions at different points in the governance and management networks in which mangroves are embedded. These interviews included a common set of open ended questions that all participants were asked, as well as contextual questions that allowed for further elaboration, following well-established social research interview protocols [70]. A diverse range of key stakeholders were invited for interview, including environmental managers and their staff in local, state and federal government agencies, ecological and biophysical scientists with an interest in mangroves and vegetation science, carbon brokers involved in the commercialisation of blue carbon, non-government staff from environment and conservation organisations working in the Darwin area, and local residents and local citizen or action groups, including Indigenous representative organisations and those involved in land management. Although over forty invitations were made to individuals and organisations connected with blue carbon and with mangroves in Darwin, fourteen interviews and two field observations with participants took place between 2017 and 2018. Most of those invited who did not participate provided no response and therefore no explanation for not participating.

For reasons elaborated in the results, the low participation rate is attributed to multiple factors including the relatively small community in Darwin associated with mangrove management and governance and the highly contentious nature of infrastructure development in Darwin harbor. Recently this has included the installation of the INPEX Ichthys gas facility, ongoing labour disputes [71] and the contentious association of funding for all Northern Territory (NT) government marine science coming from the INPEX group [72]. This issue was openly acknowledged as problematic by participants and many who agreed to take part did so with the proviso that they declined to comment on this situation. Additional factors affecting participation in the study included the relatively recent formation of a new harbour governance group. A small number of invited participants who declined to participate referenced the current environmental governance system operating in the NT affecting how they perceived their professional responsibilities in relation to mangroves. Despite these factors, over twenty hours of interviews were recorded and those who did participate represented the full diversity of the stakeholders identified above. 
The participants who did participate were asked key common questions about their professional and/or personal interactions with mangroves, including their knowledge and perspectives on how mangroves are currently valued and managed, the intersections of mangroves with existing policy and legislation, if and how they were anticipating blue carbon, as well as their perspectives on the challenges and opportunities remaining in the management of mangroves in Darwin. Additionally, in order to enrich the interview data, the author accompanied participants to observe their activities and interactions with mangroves in urban settings where possible. These field based observations and interviews included a conservation management setting and a local advocacy setting associated with multiple tenure contexts. The following analysis pays attention to the significant themes that emerged from coding or identifying analytical and emergent themes in the interview transcripts and observation notes [73]. These key themes included how effective participants viewed the current policy and legislation, how mangroves are prioritized and opportunities for enhanced mangrove protection in urban Darwin, and existing connections and opportunities for mangrove protection. All participants are referred to here with reference to their professional or personal role but names and affiliations have been omitted for privacy reasons. More than half of the study participants requested they not be identifiable in the reporting of this research due to the contentious nature of environmental management in the Northern Territory at the time of research.

\section{Results}

\subsection{Denial Versus Complacency}

Coastal zones are broadly recognised as contested spaces with multiple competing interests. However, the interviews conducted here illustrate that in northern Australia, the problems associated with coastal urban development are still viewed as a southern problem or concern and not relevant or equivalent to issues faced in the north of the continent. In this case, the threats affecting mangroves were either viewed as entirely not relevant to Darwin, or of such an insignificant scale in relation to mangroves across the Northern Territory (NT) and 'top end' more broadly, that additional conservation attention was unwarranted. For example, a view commonly encountered amongst all of the environmental professional participants working in policy, planning or science based roles was that there is 'no development problem' or pressing threat to mangroves. This view was typified by one participant who declared;

There's plenty of them, not just in the harbour, but beyond. So, compared to other pressing issues, I think collectively as a community, both the government and the public, we've resolved the issue. They've, three quarters of them, been put under conservation management. Therefore, we're now moving with other things. (Environmental professional, Darwin)

An associated perspective was that some level of impact on mangroves was both inevitable and also necessary for the development of the city. The following quote from a participant exemplifies this sentiment, noting both the relatively recent development of Darwin as a city, in comparison to the history of the southern states, as a factor to be considered in relation to decision making about mangroves.

The Territory's relatively young in its development space, so one would argue that it still has a certain segment of the coastline to develop in order to fulfil economic opportunities, and also it should be acknowledged that some of the mangroves' environment has to be compromised in order for cities to be effectively established, as is the case down south. So, most of the southern cities exist because they have impacted on their resources, used those resources in order to go ahead. (Environmental professional, Darwin)

In this example, the participant drew attention to the significance of the port in providing for and servicing the needs of the city of Darwin, and also the significance of this particular port in 
servicing national infrastructure needs. Relatedly, the contemporary impacts of development in Darwin harbour and other activities on mangroves were minimized or downplayed as spatially limited and non-consequential in the larger scheme of mangrove systems in the north. For example, one senior scientist noted, 'all cities involve development of some kind, Darwin is in its infancy, somethings gotta [got to] give'. Like the participant quoted previously, this scientist acknowledged that threats such as pollution do exist, but he minimised these threats during the interview as the reality of living in a city in the tropics.

Conversely, other interviewees, characterized as those based in more hands on or practically oriented environmental management roles and in non-governmental conservation groups, noted what they thought was widespread complacency around mangroves. For example, a senior environmental manager in a practical role explained;

As I said, the management of the mangroves for us is largely by default. So, it's largely by default that it's managed. Well, we've got a million hectares of mangroves. An extraordinary amount of mangroves in the top end. We've got this little tiny footprint ... we're doing reasonably well, except for that dieback that's happening. They don't particularly know why. So again, most of the Territory is conserved by default. (Senior environmental manager, Darwin)

This particular manager described the impacts of feral pigs and the problems associated with unregulated public access as key threats but cited the tyranny of many small decisions as the basis for widespread complacency in relation to mangrove protection. He attributed the current good state of mangroves being a function of low population pressure and low development pressure, rather than because anything had been done proactively. Participants associated with local conservation advocacy were more overt in their depiction of the problem of protecting mangroves.

We're constantly pointing out that it's still legal to clear mangroves up here, unlike many other places ... so there's no legislation protecting mangroves from being cleared. They are assessed when it comes to the [legislation]. Rarely does it trigger an EIS [environmental impact statement] up here. There's very little in place to protect mangroves at all ... So yeah, it is the Territory. Companies have put in roads through national parks without seeking any assessment. Pretty much anything goes at the moment up here. Cowboy country. (Environmental advocate, operational, Darwin)

Relatedly, some participants from advocacy groups expressed the view that the concept of blue carbon and activities associated with it, might be something that brings this problem of management failure into the spotlight.

It's like an insurance policy. We know that development's going to happen; we know that Territory's policy planning legislation is years and years behind. What can we put in place to make sure the system's integrity is maintained and we've got enough protected? So it's [blue carbon] more being used in that sense. However, people want to use it, it's up to them, but we're using it more proactively to try and get long term protections in place so the system can hopefully be resilient while we get our shit together in terms of other activities. (Environmental advocate, operational, Darwin)

These participants were acutely aware of blue carbon as a potential mechanism for mangrove protection and were already using it for their purposes to influence policy and decision making. These participants anticipated it would not be a big 'concern' in northern Australia in relation to carbon abatement projects elsewhere, but were interested in using the overarching ideas of ecosystem services as a way to keep the 'pressure' and 'spotlight' on environmental issues in the north. In political contexts, they described that carbon translates the value of mangroves well because it can do so more obviously in financial terms. For example, in a recent estimate [74] blue carbon is noted as being worth between 39-468 million dollars to the NT economy and according to participants in this research, this figure was already being used in discussions about environmental protection to advocate for protection with 
government. In this sense, advocates spoken to as part of the present study agreed that putting a dollar value on mangrove blue carbon mobilises discussions and brings them as community actors to the decision makers table, in a way that other kinds of valuations about mangroves, such as their biodiversity value, do not.

\subsection{The Cart before the Horse}

A second theme noted was broad interest in the idea of blue carbon and what it might afford in terms of mangrove recognition and protection, but either confusion about how it would work in practical terms or dismissal that it was feasible. For example, carbon brokers currently administering projects in international settings reported in this study that blue carbon was not likely to be a priority for them in Australia because although they thought it had a lot of potential, the current methodology, in their view, was being developed in a 'scientific bubble'. These participants cited compounding practical problems including little or no obvious consideration of the interaction of the methodology being considered at a federal level with the people, organisations or land managers who might want to be involved such projects. They elaborated that the current methodology was difficult to interpret and that there was little awareness amongst the community of what actions land managers and others might feasibly be doing in order to receive payments for carbon sequestration. They also cited serious reservations about the economic viability of blue carbon and that lessons learnt from terrestrial projects were not, in their view, being learnt. In this case, participants offered various current calculations of land area and carbon value as a way of calling the viability blue carbon, in a practical or economic sense, into question.

More commonly, study participants dismissed mangrove protection as a priority. One participant summarised it thus;

We don't have catchment management. We don't have catchment management bodies, so we don't have a level of co-ordination across the catchment that will actually be able to address the problems. The coast is well-valued, but it's just not a priority. (Environmental professional, Darwin)

Integrated environmental planning, or rather the lack of it in the NT, was widely cited as a key problem in relation to protecting mangroves. This absence of integrated planning was noted by most, including those from within government, as problematic in the way it influenced how agency staff interacted, or did not, across the different sectors of government, or the way it led to uncoordinated engagement and communication with the wider community. One environmental professional noted the practical and financial problems associated with introducing environmental planning into the NT, noting the small population size as a primary inhibitor.

... it is a small jurisdiction with a relatively small number of people, so the standard processes that we impose on the southern cities that are generally sophisticated, large and expensive, don't necessarily play out that well here. Primarily because there [are] not enough people to implement, monitor, and enforce. So often, in a small jurisdiction, it's better not to actually impose any rules and don't talk about it because you don't draw attention to it, for a variety of reasons. (Environmental professional, Darwin)

A surprising number of potential participants and organisations approached did not see mangroves as their particular responsibility. For example, government agencies and professional organisations responsible for, or with specific or defined responsibilities in the environment, including fish and water, defined mangroves as outside their areas of responsibility and declined to participate. More than half of the government agencies approached to participate in this study who declined to participate, cited a lack of jurisdiction to comment in relation to mangroves.

More specifically, participants who did take part cited other key and pressing priorities in relation to the city that, in their view, overshadowed specific concerns about mangroves in Darwin. Pollution concerns related to untreated sewerage effluent discharge during monsoonal rainfall events and 
sewerage odour problems for urban residents were both noted as immediate issues to be addressed. Indeed, at the time of interviews, the problems associated with developing sewerage infrastructure for Darwin's population had received considerable media attention and this problem came up during four of the 2018 interviews [75]. Participants who discussed this issue openly acknowledged the likely impacts of pollution on mangroves, but cited that managers had to prioritse people. In contrast, coastal storm surge was noted by one participant as a problem that should be a key priority and was not yet really on either the government or communities' agenda.

... we already have extremities of where the sea level rise is likely to go, so what we need to do then is draw community's and government's attention to that. That needs to be addressed. Mangroves compared to the potential risk of storm surge to private properties, consideration of [this] hazard will overshadow consideration of things like mangroves. So, what I'm trying to say is, it's off the radar. (Environmental professional, Darwin)

In this case the participant was anticipating that much of the impact and therefore the cost associated with increasing coastal flooding was likely to be borne by private landholders. At the same time he, and other participants citing higher order priorities, were aware that the current environmental governance system operating in the NT was viewed as, or indeed experienced as 'highly reactive'. In other words, even those who did not think mangrove protection was an immediate priority recognised the tensions and difficulties in having to choose between such competing and immediate concerns and the consequences of delaying proactive environmental protection.

\subsection{Existing Protections and Community Sentiment}

The third and final theme addressed here concerns existing sentiment, efforts and mechanisms to protect mangroves in Darwin and the ways participants felt these are often overlooked and/or unrecognised in wider environmental protection and governance discussions. A key issue nearly all participants mentioned or wanted to discuss in the process of this study was what was described as the close connections between the community and mangroves in Darwin.

The cultural significance of the extensive shell mounds of Darwin harbour and surrounds have been described at length in the archaeological literature, including their significance for urban based Aboriginal people (see for example [76-78]). Aboriginal use of mangroves in Darwin, including by Larrakia people and more recently also Aboriginal people who must come into Darwin for services, was widely mentioned within interviews in this study as a key way in which Aboriginal people actively continued to use mangrove areas and maintain connections to these environments in the city. In both of the walking interviews conducted, significant evidence of contemporary meals or 'dinner camps' was also encountered in the mangroves, underscoring the long history of use and occupation of these areas. On the ground surface, contemporary meals of mud whelks (Telescopium telescopium) sit on top of extensive middens that often rim the perimeter of mangrove stands. The idea of active use and occupation of urban mangroves is sometimes problematized, for example as itinerancy, a perspective discussed in detail elsewhere $[79,80]$. However, in this study, contemporary Aboriginal occupation and use of mangroves was mentioned by study participants to ground their explanations of the services urban mangroves provided to communities, and which are often unacknowledged. For example, non-Aboriginal participants noted that while they themselves might not obtain food from mangroves, they readily acknowledged the food available to Aboriginal residents and others who might rely on this food source and in turn how this food source is vital because of its urban context. In this case, the current legal parameters and context around payments for blue carbon as a mechanism that might protect mangroves, was discussed as being both hopeful but simultaneously problematic and uncertain for Aboriginal people, because it did not as yet overtly engage with the Indigenous communities who actively use mangroves for subsistence purposes. 
Recreational fishers were another community sector identified by participants as being significant in relation to mechanisms or actions that might protect mangroves. The following quote summarises this relationship.

I think only to say that in Darwin, in the Top End, people are very connected to their environments. They're out in their environments a lot. And therefore, people are ... quite passionate about ensuring that their background is looked after, their playground, for a lot of them. So we're very fortunate that people have a relatively high level awareness and care for-like, you'd be hard off finding someone up here who doesn't, to some extent, understand the value of mangroves, even if they're just like, "Well, the fish live in there." And then people catch those fish ... people see mangroves every day. Even out in the suburbs there's patches of them. People love them. Even if they bring midges, people are OK with that! (Environmental advocate, operational, Darwin)

Fishers were widely discussed as being both outspoken in voicing their concerns about impacts to mangroves and also key stakeholders in the way their observations of mangroves had brought the issue of mangrove dieback to scientist's attention. In interviews with scientists, the concerns of fishers were mostly viewed as positive but also potentially naïve, in the sense that extensive long term monitoring did not exist and also that fishers were making at times direct and simplistic connections between the health of mangroves and the health of fish populations. For example, one participant, a scientist, explained that he could not say for sure that fishers 'care' about mangroves, rather that fishers would lobby for mangroves to the extent that mangroves were important for fish.

The emphasis on broad community connection to mangroves and positive understanding of their value was widely cited as a factor that made advocacy around environmental protection a relatively easy conversation to have in Darwin. Key advocacy success concerning specific developments associated with mangroves also emerged in interviews with participants who had resided in Darwin for many decades. One community member invited the author to discuss blue carbon at the Ludmilla Creek salt pan at East Point Reserve, now a listed heritage site [81], where mangroves had been significant in local community campaigns and success to limit the development of a large boat marina.

So, it was eventually heritage listed, and very thankfully, in the same year [2009] there was a project that came out that wanted to build a huge super-yacht marina here ... we really targeted all the markets, had a huge public meeting with scientists talking about mangroves and tidal surges .... I was amazed at people's response. I think it was, it only took us two months before the government decided that that proposal wasn't a very good idea. It was amazing how we all came together, and it worked. People power! (Local community member, Darwin)

During this walking interview, there was a diversity of values evident, including Aboriginal and post-European heritage use of the area as the site of the first salt works in northern Australia, and key biodiversity values in the form of habitat for migratory birds. However, this participant highlighted that it was the heritage listing that was eventually upheld in this development assessment case. Although a previous quote above pointed to the difficulties presented by a small population size in relation to environmental protection, services and regulation, in contrast this participant also emphasized that the strength of connections and the small population of Darwin had made it possible to get political attention and have direct influence in terms of decision making.

\section{Discussion}

This study has sought to highlight contemporary community perspectives on mangroves in urban Darwin, within the context of national governance moves in Australia to reframe and therefore value mangrove ecosystems as blue carbon. The research reported here was challenged by the political context and controversy surrounding recent heavy industry development projects and their impacts on mangrove environments in Darwin harbour, the relatively small community of Darwin and its inherent connectedness, and by the emergent and therefore uncertain policy setting and practical operation of 
blue carbon, within the Australian management context. Never-the-less this study offers key insights, as well as avenues for future research, into the way mangroves are currently understood, used and managed and the diverse ways in which blue carbon is being anticipated or already actively mobilized conceptually in environmental management contexts.

One key insight provided is the limitations of the current governance and policy setting in the Northern Territory and its capacity to provide connected or integrated environmental management and deliver mangrove protection. This is especially relevant given the disjuncture of mangroves portrayed as 'pristine' systems in northern Australia but also the inherent interconnectedness of mangroves and urban Darwin in terms of urban impacts and threats $[63,65]$. While most states in Australia protect coastal ecosystems explicitly [61], the results presented here indicate how a lack of integrated planning in the NT is experienced as a frustrating and obvious problem and how such policy gaps present clear practical challenges to mangrove protection. While participants working in policy, and even science based roles were often times dismissive about the need for improved mangrove conservation in the harbour, managers who worked practical hands on roles all indicated mangroves are in fact not a priority, not actively managed and only protected by default. In this context, conversations about blue carbon and the possibility of payments for the carbon sequestration they might provide, were viewed by study participants as irrelevant or even as inappropriate for good environmental governance. Further, such conversations at times provoked suspicion and played into community fears and discourse about the role of the federal government (where most blue carbon policy and science work is currently taking place) in exerting control over Territory self-governance [82]. In contrast, the results presented here illustrate how informal or vernacular protection was afforded by the close connections that some groups in Darwin's community have with mangrove ecosystems, suggesting alternative and locally relevant ways in which mangroves are valued and can be protected in the absence of formalised governance and limited resources.

However, despite this context, and despite not yet being part of the current national emissions reduction scheme or voluntary schemes, the research illustrates that the idea of blue carbon is already subtly working in unanticipated ways to influence Territory and local decision makers. There it still a lot that is unknown about the blue carbon methodology being proposed at the federal level, but particular interest groups are already inserting the idea or the possibility of future payments for blue carbon into their advocacy activities in Territory jurisdictions. In other words, although blue carbon is not yet operationalized, the concept is being used by advocacy groups as a 'boundary object' to translate environmental economics and the value of mangroves to decision makers. Influential others such as carbon brokers, who might be key players in advancing blue carbon at an operational level, have already taken the view and/or made business operating decisions that blue carbon will not be feasible or will not be useful for them. There were a range of concerns from these participants about failure to learn the lessons of the past, either about likely co-benefits for landholders who might in future buy into blue carbon projects, or alternatively perverse outcomes associated with payments whereby those who've made the biggest modifications to ecosystems may in fact stand to benefit the most from payments for carbon services (a possible consequence of what is known as the additionality clause). A key observation from this study is that communities who might have more practical interests in the process of revaluing mangroves through payments for ecosystem services are not yet part of the process of developing a methodology for blue carbon. This situation risks alienating communities with interest from the process, and/or rendering the outcomes irrelevant.

Relatedly, ecosystem service frameworks would be enriched from the depth of learning available in research of cultural landscapes and cultural heritage valuation [83]. The present study illustrates how social and cultural heritage values were mobilised during a moment of conflicting social interests and how heritage governance held sway in the process of assessing a marina development. Local heritage values in this case were seen to be hugely effective when it came to mobilising and connecting parts of the community against a development that would remove mangroves. The challenge for those advancing mangrove conservation and protection by framing them in particular ways (such as through 
payments for blue carbon) then, is to remember that mangroves are part of landscapes that are social and cultural as well as ecological, and that there may already be important local mechanisms in place for valuing and protecting mangroves, but which may appear incidental in dominant framings of them as natural and biological systems. Social and cultural heritage values are, arguably, not well recognized as relevant to protecting mangroves, and are under-utilised in the Australian context, and as such, warrant further research attention with reference to the existing conservation regime [84].

Participants in the present study commonly situated their views about Darwin's mangroves and the challenges faced from development in the context of global mangrove ecologies and national infrastructure needs. This constant reference to and positioning of Darwin's mangroves in national or even global contexts was used by study participants both to justify and downplay the potential impact of clearing mangroves in Darwin, and conversely to highlight why they should not be cleared. From both perspectives, the research illustrates an important conceptual gap in community understandings of mangroves as green infrastructure and as an inherent part of the life and functioning of Darwin as an urban environment, for those who sought to downplay or highlight mangrove protection alike, spoke of them as systems whose presence and integrity is not compatible with future urban development. Using very different empirical data, this finding supports research reported elsewhere [85] that interpretations of vegetation as nature, can be antithetical to understandings of what constitutes the urban. A key contribution in this regard is that geographic locality or the situation and proximity of trees and other vegetation within urban contexts does not automatically determine how communities recognize, associate or even prioritise systems of value, and should not be assumed.

Mangroves therefore are not just part of a physical 'in between' space, between the land and the sea, they also signify or locate an important conceptual liminal space between urban green infrastructure and climate mitigation or blue carbon infrastructure and how mangroves are positioned as being part of, or integral to, urban life. In this regard, this article represents an important contribution to key knowledge gaps on the social dimensions of blue carbon [86] and contrasts with emergent research elsewhere on stakeholder perspectives of urban mangrove management, particularly in terms of what constitutes effective management and protection [87]. Whether it is possible to adequately conceive of and maintain mangroves as urban green infrastructure will require ongoing examination of the intersections of these emergent or developing concepts, not only to ensure the concepts themselves are inclusive, relevant and robust, but also to ensure that practical efforts to reconfigure urban decision making around climate change is adequate and responsive to its geographical context.

Funding: This research was funded by a University of Wollongong Global Challenges grant awarded to K. Rogers, J. Atchison, Q. Hanich, M. Kaidonis, R, Warner, and C. Woodroffe entitled 'Blue Carbon Futures: Improving carbon sequestration in mangroves across Australia, Vietnam and Brazil'.

Acknowledgments: The author gratefully acknowledges the time that research participants gave to the project and their contribution to social environmental research under trying circumstances. Kerrylee Rogers and Drauzio Annunciato provided collegial and practical support in the development of this research. Three anonymous reviewers provided generous and constructive reviews.

Conflicts of Interest: The author declares no conflict of interest. This research was approved by the University of Wollongong Human Research Ethics Committee, protocol 2017/128.

\section{References}

1. Gill, S.E.; Handley, J.F.; Ennos, A.R.; Pauleit, S. Adapting cities for climate change: The role of the green infrastructure. Built Environ. 2007, 33, 115-133. [CrossRef]

2. Gaffin, S.R.; Rosenzweig, C.; Kong, A.Y. Adapting to climate change through urban green infrastructure. Nat. Clim. Chang. 2012, 2, 704. [CrossRef]

3. Demuzere, M.; Orru, K.; Heidrich, O.; Olazabal, E.; Geneletti, D.; Orru, H.; Bhave, A.G.; Mittal, N.; Feliu, E.; Faehnle, M. Mitigating and adapting to climate change: Multi-functional and multi-scale assessment of green urban infrastructure. J. Environ. Manag. 2014, 146, 107-115. [CrossRef] [PubMed] 
4. Norton, B.A.; Coutts, A.M.; Livesley, S.J.; Harris, R.J.; Hunter, A.M.; Williams, N.S. Planning for cooler cities: A framework to prioritise green infrastructure to mitigate high temperatures in urban landscapes. Landsc. Urban Plan. 2015, 134, 127-138. [CrossRef]

5. Jayasooriya, V.M.; Ng, A.W.M.; Muthkumaran, S.; Perera, B.J.C. Green infrastructure practices for improvement of urban air quality. Urban For. Urban Green. 2017, 21, 34-47. [CrossRef]

6. Coutts, C.; Hahn, M. Green infrastructure, ecosystem services, and human health. Int. J. Environ. Res. Public Health 2015, 12, 9768-9798. [CrossRef] [PubMed]

7. Cadenasso, M.L.; Pickett, S.T.; Schwarz, K. Spatial heterogeneity in urban ecosystems: Reconceptualising land cover and a framework for classification. Front Ecol. Environ. 2007, 5, 80-88. [CrossRef]

8. Pickett, S.T.; Cadenasso, M.L. Linking ecological and built components of urban mosaics: An open cycle of ecological design. J. Ecol. 2008, 96, 8-12. [CrossRef]

9. Bun, M.; Jones, R.; Lorimer, C.; Pitman, S.; Thorpe, R. The 202020 Vision Plan; Horticulture Innovation Australia: Sydney, Australia, 2015. Available online: https://202020vision.com.au/media/41955/202020visionplan.pdf (accessed on 27 June 2019).

10. Mell, I.; Allin, S.; Reimer, M.; Wilker, J. Strategic green infrastructure planning in Germany and the UK: A transnational evaluation of the evolution of urban greening policy and practice. Int. Plan. Stud. 2017, 22, 333-349. [CrossRef]

11. Brunner, J.; Cozens, P. 'Where have all the trees gone?' Urban consolidation and the demise of urban vegetation: A case study from Western Australia. Plan. Pract. Res. 2013, 28, 231-255. [CrossRef]

12. Breuste, J.H. Decision making, planning and design for the conservation of indigenous vegetation within urban development. Landsc. Urban Plan. 2004, 68, 439-452. [CrossRef]

13. Alvey, A.A. Promoting and preserving biodiversity in the urban forest. Urban For. Urban Green. 2006, 5, 195-201. [CrossRef]

14. Dümpelmann, S. Seeing Trees: A History of Street Trees in New York City and Berlin; Yale University Press: New Haven, CT, USA, 2019.

15. Guo, T.; Morgenroth, J.; Conway, T. Redeveloping the urban forest: The effect of redevelopment and property-scale variables on tree removal and retention. Urban For. Urban Green. 2018, 35, 192-201. [CrossRef]

16. Steenberg, J.W.; Robinson, P.J.; Millward, A.A. The influence of building renovation and rental housing on urban trees. J. Environ. Plan. Manag. 2018, 61, 553-567. [CrossRef]

17. Bai, X.; Dawson, R.J.; Ürge-Vorsatz, D.; Delgado, G.C.; Barau, A.S.; Dhakal, S.; Dodman, D.; Leonardsen, L.; Masson-Delmotte, V.; Roberts, D.C.; et al. Six research priorities for cities and climate change. Nature 2018, 555, 23-25. [CrossRef]

18. Chen, R.; Zhang, Y.; Xu, D.; Liu, M. Climate change and coastal megacities: Disaster risk assessment and responses in shanghai city. In Climate Change, Extreme Events and Disaster Risk Reduction; Mal, S., Singh, R.B., Huggel, C., Eds.; Springer: Cham, Switzerland, 2018; pp. 203-216.

19. McGranahan, G.; Balk, D.; Anderson, B. The rising tide: Assessing the risks of climate change and human settlements in low elevation coastal zones. Environ. Urban. 2007, 19, 17-37. [CrossRef]

20. Richards, D.R.; Passy, P.; Oh, R.R. Impacts of population density and wealth on the quantity and structure of urban green space in tropical Southeast Asia. Landsc. Urban Plan. 2017, 157, 553-560. [CrossRef]

21. Koc, C.B.; Osmond, P.; Peters, A. Towards a comprehensive green infrastructure typology: A systematic review of approaches, methods and typologies. Urban Ecosyst. 2017, 20, 15-35.

22. Kati, V.; Jari, N. Bottom-up thinking-Identifying socio-cultural values of ecosystem services in local blue-green infrastructure planning in Helsinki, Finland. Land Use Policy 2016, 50, 537-547. [CrossRef]

23. Šijanec Zavrl, M.; Tanac Zeren, M. Sustainability of urban infrastructures. Sustainability 2010, 2, $2950-2964$. [CrossRef]

24. Garmendia, E.; Apostolopoulou, E.; Adams, W.M.; Bormpoudakis, D. Biodiversity and Green Infrastructure in Europe: Boundary object or ecological trap? Land Use Policy 2016, 56, 315-319. [CrossRef]

25. Wright, H. Understanding green infrastructure: The development of a contested concept in England. Local Environ. 2011, 16, 1003-1019. [CrossRef]

26. Borie, M.; Hulme, M. Framing global biodiversity: IPBES between mother earth and ecosystem services. Environ. Sci. Policy 2015, 54, 487-496. [CrossRef]

27. Kull, C.A.; de Sartre, X.A.; Castro-Larrañaga, M. The political ecology of ecosystem services. Geoforum 2015, 61, 122-134. [CrossRef] 
28. Da Silva, J.M.C.; Wheeler, E. Ecosystems as infrastructure. Pers. Ecol. Conserv. 2017, 15, 32-35. [CrossRef]

29. Montgomery, J.M.; Bryan, K.R.; Mullarney, J.C.; Horstman, E.M. Attenuation of storm surges by coastal mangroves. Geophys. Res. Lett. 2019, 46, 2680-2689. [CrossRef]

30. Barbier, E.B. Valuing the storm protection service of estuarine and coastal ecosystems. Ecosyst. Serv. 2015, 11, 32-38. [CrossRef]

31. Thomas, N.; Lucas, R.; Bunting, P.; Hardy, A.; Rosenqvist, A.; Simard, M. Distribution and drivers of global mangrove forest change, 1996-2010. PLoS ONE 2017, 12, e0179302. [CrossRef]

32. Everard, M.; Jha, R.R.; Russell, S. The benefits of fringing mangrove systems to Mumbai. Aquat. Conserv. Mar. Freshw. Ecosyst. 2014, 24, 256-274. [CrossRef]

33. Beja da Costa, A.; Ribeiro, L. On the Coastline: The Genesis of Green Infrastructure Towards a Future Sustainable Landscape for the City of Maputo, Mozambique. Proc. Fábos Conf. Landsc. Greenway Plan. 2019, 6,6 .

34. Morris, R.L.; Konlechner, T.M.; Ghisalberti, M.; Swearer, S.E. From grey to green: Efficacy of eco-engineering solutions for nature-based coastal defence. Glob. Chang. Biol. 2018, 24, 1827-1842. [CrossRef] [PubMed]

35. Timm, M.R.; Araújo, R.J. Comparisons of south Florida's seawall and natural mangrove stands reveal similar structural attributes. Urban For. Urban Green. 2018, 32, 7-20. [CrossRef]

36. Mayer-Pinto, M.; Johnston, E.L.; Bugnot, A.B.; Glasby, T.M.; Airoldi, L.; Mitchell, A.; Dafforn, K.A. Building 'blue': An eco-engineering framework for foreshore developments. J. Environ. Manag. 2017, 189, 109-114. [CrossRef] [PubMed]

37. Sutton-Grier, A.E.; Wowk, K.; Bamford, H. Future of our coasts: The potential for natural and hybrid infrastructure to enhance the resilience of our coastal communities, economies and ecosystems. Environ. Sci. Pol. 2015, 51, 137-148. [CrossRef]

38. Lee, S.Y.; Primavera, J.H.; Dahdouh-Guebas, F.; McKee, K.; Bosire, J.O.; Cannicci, S.; Diele, K.; Fromard, F.; Koedam, N.; Marchand, C.; et al. Ecological role and services of tropical mangrove ecosystems: A reassessment. Glob. Ecol. Biogeogr. 2014, 23, 726-743. [CrossRef]

39. Mcleod, E.; Chmura, G.L.; Bouillon, S.; Salm, R.; Björk, M.; Duarte, C.M.; Lovelock, C.E.; Schlesinger, W.H.; Silliman, B.R. A blueprint for blue carbon: Toward an improved understanding of the role of vegetated coastal habitats in sequestering $\mathrm{CO}_{2}$. Front. Ecol. Environ. 2011, 9, 552-560. [CrossRef]

40. Friess, D.A.; Richards, D.R.; Phang, V.X. Mangrove forests store high densities of carbon across the tropical urban landscape of Singapore. Urban Ecosyst. 2016, 19, 795-810. [CrossRef]

41. Pauli, G.A. The Blue Economy: 10 Years, 100 Innovations, 100 Million Jobs; Paradigm Publications: Brookline, MA, USA, 2010.

42. Locatelli, T.; Binet, T.; Kairo, J.G.; King, L.; Madden, S.; Patenaude, G.; Upton, C.; Huxham, M. Turning the tide: How blue carbon and payments for ecosystem services (PES) might help save mangrove forests. Ambio 2014, 43, 981-995. [CrossRef] [PubMed]

43. Steven, A.D.; Vanderklift, M.A.; Bohler-Muller, N. A new narrative for the blue economy and blue carbon. J. Indian Ocean. Reg. 2019, 15, 123-128. [CrossRef]

44. Walton, N.; Fitzsimons, J. Payment for ecosystem services in practice-savanna burning and carbon abatement at Fish River, northern Australia. In Valuing Nature: Protected Areas and Ecosystem Services; Figgis, P., Mackey, B., Fitzsimons, J., Irving, J., Clarke, P., Eds.; Australian Committee for IUCN: Sydney, Australia, 2015; pp. 78-83.

45. Bradshaw, C.J.; Bowman, D.M.; Bond, N.R.; Murphy, B.P.; Moore, A.D.; Fordham, D.A.; Thackway, R.; Lawes, M.J.; McCallum, H.; Gregory, S.D.; et al. Brave new green world-consequences of a carbon economy for the conservation of Australian biodiversity. Biol. Conserv. 2013, 161, 71-90. [CrossRef]

46. Newell, P.; Boykoff, M.; Boyd, E. (Eds.) The New Carbon Economy: Constitution, Governance and Contestation; John Wiley \& Sons: Hoboken, NJ, USA, 2012; p. 48.

47. Bridge, G. Resource geographies 1: Making carbon economies, old and new. Prog. Hum. Geogr. 2011, 35, 820-834. [CrossRef]

48. Russell-Smith, J.; Yates, C.P.; Edwards, A.C.; Whitehead, P.J.; Murphy, B.P.; Lawes, M.J. Deriving multiple benefits from carbon market-based savanna fire management: An Australian example. PLoS ONE 2015, 10, e0143426. [CrossRef] [PubMed]

49. Jackson, S.; Palmer, L.; McDonald, F.; Bumpus, A. Cultures of carbon and the logic of care: The possibilities for carbon enrichment and its cultural signature. Ann. Ass. Am. Geogr. 2017, 107, 867-882. [CrossRef] 
50. Robinson, C.J.; Renwick, A.R.; May, T.; Gerrard, E.; Foley, R.; Battaglia, M.; Possingham, H.; Griggs, D.; Walker, D. Indigenous benefits and carbon offset schemes: An Australian case study. Environ. Sci. Pol. 2016, 56, 129-134. [CrossRef]

51. Torabi, N.; Mata, L.; Gordon, A.; Garrard, G.; Wescott, W.; Dettmann, P.; Bekessy, S.A. The money or the trees: What drives landholders' participation in biodiverse carbon plantings? Glob. Ecol. Conserv. 2016, 7, 1-11. [CrossRef]

52. Muradian, R.; Arsel, M.; Pellegrini, L.; Adaman, F.; Aguilar, B.; Agarwal, B.; Corbera, E.; Ezzine de Blas, D.; Farley, J.; Froger, G.; et al. Payments for ecosystem services and the fatal attraction of win-win solutions. Conserv. Lett. 2013, 6, 274-279. [CrossRef]

53. McAfee, K. Green economy and carbon markets for conservation and development: A critical view. Int. Environ. Agreem. Pol. Law Econ. 2016, 16, 333-353. [CrossRef]

54. Wylie, L.; Sutton-Grier, A.E.; Moore, A. Keys to successful blue carbon projects: Lessons learned from global case studies. Mar. Pol. 2016, 65, 76-84. [CrossRef]

55. Rogers, K.; Macreadie, P.I.; Kelleway, J.J.; Saintilan, N. Blue carbon in coastal landscapes: A spatial framework for assessment of stocks and additionality. Sustain. Sci. 2019, 14, 453-467. [CrossRef]

56. Himes-Cornell, A.; Pendleton, L.; Atiyah, P. Valuing ecosystem services from blue forests: A systematic review of the valuation of salt marshes, sea grass beds and mangrove forests. Ecosyst. Serv. 2018, 30, 36-48. [CrossRef]

57. Goodall, H.; Cadzow, A.; Byrne, D. Mangroves, garbage, fishing: Bringing everyday ecology to Sydney's industrial Georges River. Trans. Cult. EJ 2010, 5, 1. [CrossRef]

58. Wolanski, E.; Ducrotoy, J.P. Estuaries of Australia in 2050 and beyond-A synthesis. In Estuaries of Australia in 2050 and Beyond; Wolanski, E., Ed.; Springer: Dordrecht, The Netherlands, 2014; pp. 1-13.

59. Kelleway, J.; Serrano, O.; Baldock, J.; Cannard, T.; Lavery, P.; Lovelock, C.E.; Saintilan, N.; Steven, A.D.L. Technical Review of Opportunities for Including Blue Carbon in the Australian Government's Emissions Reduction Fund; CSIRO: Canberra, Australia, 2017.

60. Humphries, F.; Anton, D.; Tan, P.L.; Akhtar-Khavari, A.; Butler, C. Ecological Governance and the Development Plan for Northern Australia. Australian Environment Review, 17-22 May 2017. Griffith University Law School Research Paper No. 17-12. Available online: https://ssrn.com/abstract=2921348 (accessed on 26 July 2019).

61. Saintilan, N.; Rogers, K.; Kelleway, J.J.; Ens, E.; Sloane, D.R. Climate change impacts on the coastal wetlands of Australia. Wetlands 2018, 1-10. [CrossRef]

62. Alongi, D.D.; Metcalfe, K.K.; Townsend, S.S.; Leiper, I.I. Review of Research and Monitoring of Darwin Harbour's Mangrove Environment for the Development of a Long-Term Monitoring Program. 2016. Available online: http://epubs.aims.gov.au/11068/13054 (accessed on 26 July 2019).

63. Munksgaard, N.C.; Hutley, L.B.; Metcalfe, K.N.; Padovan, A.C.; Palmer, C.; Gibb, K.S. Environmental challenges in a near-pristine mangrove estuary facing rapid urban and industrial development: Darwin Harbour, Northern Australia. Reg. Stud. Mar. Sci. 2019, 25. [CrossRef]

64. Darwin Harbour Advisory Committee. Darwin Harbour Regional Plan of Management. 2003. Available online: https://nt.gov.au/_data/assets/pdf_file/0007/661804/darwin-harbour-strategy-managent-plan-2003. pdf (accessed on 26 July 2019).

65. Semeniuk, V.; Cresswell, I.D. Australian mangroves: Anthropogenic impacts by industry, agriculture, ports, and urbanisation. In Threats to Mangrove Forests; Makowski, C., Finkl, C., Eds.; Springer: Cham, Switzerland, 2018; Volume 25, pp. 173-197.

66. Datta, D.; Chattopadhyay, R.N.; Guha, P. Community based mangrove management: A review on status and sustainability. J. Environ. Manag. 2012, 107, 84-95. [CrossRef] [PubMed]

67. Warner, R.; Kaidonis, M.; Dun, O.; Rogers, K.; Shi, Y.; Nguyen, T.T.; Woodroffe, C.D. Opportunities and challenges for mangrove carbon sequestration in the Mekong River Delta in Vietnam. Sustain. Sci. 2016, 11, 661-677. [CrossRef]

68. Fish, R.; Church, A.; Winter, M. Conceptualising cultural ecosystem services: A novel framework for research and critical engagement. Ecosyst. Serv. 2016, 21, 208-217. [CrossRef]

69. Tsing, A. Friction. An Ethnography of Global Connection; Princeton University Press: Princeton, NJ, USA, 2015.

70. Longhurst, R. Semi-structured Interviews and Focus Groups. In Key Methods in Geography; Clifford, N., Cope, M., Gillespie, T.S., French, S., Eds.; Sage: London, UK, 2016; pp. 143-156. 
71. Australian Broadcasting Commission (ABC). INPEX: More than 800 Workers Stood Down from $\$ 36 \mathrm{~B}$ Gas Project. 2017. Available online: https://www.abc.net.au/news/2017-03-15/inpex-gas-project-darwin-workersstood-down-laing-orouke-jkc/8355386?pfmredir=sm (accessed on 26 July 2019).

72. Australian Broadcasting Commission (ABC). NT Department of Environment Admits Gas Giant Inpex must 'Approve' Interviews with Its Scientists. 2018. Available online: https://www.abc.net.au/news/2018-09-19/ inpex-nt-department-environment-approve-scientists-public-media/10268362 (accessed on 26 July 2019).

73. Cope, M.; Kurtz, H. Organising, coding and analysing qualitative data. In Key Methods in Geography; Sage: London, UK, 2016; pp. 647-664.

74. Crossman, N.D.; Stoeckl, N.; Sangha, K.; Costanza, R. Economic Values of the Northern Territory Marine and Coastal Environments; Australian Marine Conservation Society: Darwin, Australia, 2018.

75. Shipway, G. Heavy Rains Causing Sewerage Spill Problems in Darwin Suburbs. NT News. 2017. Available online: https://www.ntnews.com.au/news/northern-territory/heavy-rains-causing-sewage-spill-problemsin-darwin-suburbs/news-story/5601c7c5727e6fcfc226dc71e978491c (accessed on 31 May 2019).

76. Bourke, P.M. Identifying Aboriginal 'contact period' sites around Darwin: Long past due for native title? Aust. Ab. Stud. 2005, 1, 54.

77. Hiscock, P.; Hughes, P. Prehistoric and World War II use of shell mounds in Darwin Harbour. Aust. Arch. 2001, 52, 41-45. [CrossRef]

78. Burns, T. Subsistence and settlement patterns in the Darwin coastal region during the late Holocene period: A preliminary report of archaeological research. Aust. Ab. Stud. 1999, 1, 59.

79. Lobo, M. Racialised bodies encounter the city: 'Long Grassers' and asylum seekers in Darwin. J. Intercult. Stud. 2013, 34, 454-465. [CrossRef]

80. Fisher, D. Running amok or just sleeping rough? Long-grass camping and the politics of care in northern Australia. Am. Ethnol. 2012, 39, 171-186. [CrossRef]

81. NT Government. Ludmilla Salt Pans Heritage Register. 2009. Available online: http://www.ntlis.nt.gov.au/ heritageregister/f?p=103:302:2593089051445471::NO::P302_SITE_ID:891 (accessed on 26 July 2019).

82. Heatley, A. Almost Australians: The Politics of Northern Territory Self-Government; The Australian National University: Brinkin, Australia; North Australia Research Unit (NARU): Darwin, Australia, 1990.

83. Tengberg, A.; Fredholm, S.; Eliasson, I.; Knez, I.; Saltzman, K.; Wetterberg, O. Cultural ecosystem services provided by landscapes: Assessment of heritage values and identity. Ecosyst. Serv. 2012, 2, 14-26. [CrossRef]

84. Cresswell, I.D.; Semeniuk, V. Australian Mangroves: Their Distribution and protection. In Threats to Mangrove Forests: Hazards, Vulnerability, and Management; Makowski, C., Finkl, C., Eds.; Springer: Cham, Switzerland, 2018; Volume 25, pp. 3-22.

85. Taylor, L.; Hochuli, D.F. Defining greenspace: Multiple uses across multiple disciplines. Landsc. Urban Plan. 2017, 158, 25-38. [CrossRef]

86. Thomas, S. Blue carbon: Knowledge gaps, critical issues, and novel approaches. Ecol. Econ. 2014, 107, $22-38$. [CrossRef]

87. Vane Velda, K.; Huge, J.; Friess, D.; Koedam, N.; Dahdouh-Guebas, F. Stakeholder discourses on urban mangrove conservation and management. Ocean Coast. Manag. 2019, 178, 104810. [CrossRef]

(C) 2019 by the author. Licensee MDPI, Basel, Switzerland. This article is an open access article distributed under the terms and conditions of the Creative Commons Attribution (CC BY) license (http://creativecommons.org/licenses/by/4.0/). 